Article

\title{
Evaluation of $\mathrm{Pb}, \mathrm{Mg}, \mathrm{Al}, \mathrm{Zn}$, and $\mathrm{Cu}$ as Electrode Materials in the Electrocoagulation of Microalgae
}

\author{
Jesse T. Phiri $\mathbb{D}$, Hun Pak, Junhyung We and Sanghwa Oh *D \\ School of Architectural, Civil, Environmental and Energy Engineering, Kyungpook National University, \\ Daegu 41566, Korea; jesset.phiri@knu.ac.kr (J.T.P.); ph6524@knu.ac.kr (H.P.); gud6417@knu.ac.kr (J.W.) \\ * Correspondence: shoh@knu.ac.kr; Tel.: +82-53-950-5609
}

Citation: Phiri, J.T.; Pak, H.; We, J.; $\mathrm{Oh}, \mathrm{S}$. Evaluation of $\mathrm{Pb}, \mathrm{Mg}, \mathrm{Al}, \mathrm{Zn}$, and $\mathrm{Cu}$ as Electrode Materials in the Electrocoagulation of Microalgae. Processes 2021, 9, 1769. https:// doi.org/10.3390/pr9101769

Academic Editor: Bipro R. Dhar

Received: 27 July 2021

Accepted: 29 September 2021

Published: 2 October 2021

Publisher's Note: MDPI stays neutral with regard to jurisdictional claims in published maps and institutional affiliations.

Copyright: (c) 2021 by the authors. Licensee MDPI, Basel, Switzerland. This article is an open access article distributed under the terms and conditions of the Creative Commons Attribution (CC BY) license (https:// creativecommons.org/licenses/by/ $4.0 /)$.

\begin{abstract}
Apart from the conventionally used iron ( $\mathrm{Fe})$ and aluminum ( $\mathrm{Al})$ electrodes in microalgae harvesting, experiments were designed to examine the viability of lead $(\mathrm{Pb})$, magnesium $(\mathrm{Mg})$, zinc $(\mathrm{Zn})$, and copper $(\mathrm{Cu})$ as electrode materials in the harvesting of microalgae. The effect of voltage on the flocculation efficiency (FE) of the electrode materials was examined and compared. By dividing the optimal FE values by their corresponding periods, a simple yet practical approach was used to rank the electrode materials. From highest to lowest flocculation efficiency, the results were as follows: $\mathrm{Cu}, \mathrm{Zn}, \mathrm{Mg}, \mathrm{Al}$, and $\mathrm{Pb}$ at $10 \mathrm{~V} ; \mathrm{Mg}, \mathrm{Zn}, \mathrm{Cu}, \mathrm{Al}$, and $\mathrm{Pb}$ at $20 \mathrm{~V}$; and $\mathrm{Mg}, \mathrm{Zn}, \mathrm{Al}, \mathrm{Cu}$, and $\mathrm{Pb}$ at $30 \mathrm{~V}$. Important factors such as temperature, periodic FE, consumption of electrode material, $\mathrm{pH}$, and metallic concentrations in the effluent were evaluated. The temperature increase proposed to have been affected by electric resistance drop and anodic corrosion, between $1.7^{\circ} \mathrm{C}$ and $3.3^{\circ} \mathrm{C}$, $5{ }^{\circ} \mathrm{C}$ and $8.9^{\circ} \mathrm{C}$, and $10.5^{\circ} \mathrm{C}$ and $18.4^{\circ} \mathrm{C}$ was recorded at $10 \mathrm{~V}, 20 \mathrm{~V}$, and $30 \mathrm{~V}$ respectively. Except for the supernatants of the experiments from $\mathrm{Al}$ electrodes, which remained relatively unaffected by voltage and time, the $\mathrm{pH}$ of all the other supernatants increased with time and voltage. The effluents recorded metallic concentrations between $0.513 \mathrm{mg} / \mathrm{L}$ and $43.8 \mathrm{mg} / \mathrm{L}$ for $\mathrm{Pb}, 7.02 \mathrm{mg} / \mathrm{L}$ and $20.5 \mathrm{mg} / \mathrm{L}$ for $\mathrm{Mg}, 1.34 \mathrm{mg} / \mathrm{L}$ and $9.09 \mathrm{mg} / \mathrm{L}$ for $\mathrm{Al}, 0.079 \mathrm{mg} / \mathrm{L}$ and $0.089 \mathrm{mg} / \mathrm{L}$ for $\mathrm{Zn}$, and $0.252 \mathrm{mg} / \mathrm{L}$ and $0.434 \mathrm{mg} / \mathrm{L}$ for Cu electrodes.
\end{abstract}

Keywords: electrocoagulation; microalgae; lead; magnesium; aluminum; zinc; copper

\section{Introduction}

Recent concerns for global warming have ushered scientists into extensive research on biomass fuel as an alternative to fossil fuels. One such ongoing study showing prominent results is microalgae biofuels [1]. Microalgae are unicellular micro-organisms that capture energy from light and carbon dioxide from the environment for cell development [2]. It has been established that the cultivation of microalgae aids the reduction of $\mathrm{CO}_{2}$ levels in the atmosphere [3], at the same time providing an alternative source of energy to diminishing fossil fuels. Furthermore, the unicellular nature of microalgae has piqued scientists' interest in doing additional research on microalgae biomass production as it implies ease to culture and minimal upkeep. Even though the culturing of microalgae requires minimal supervision [4], the process of harvesting microalgae has proven to be complicated [5]. This is mainly due to the microscopic size of microalgae cells (5-10 $\mu \mathrm{m}$ for Chlorella vulgaris) and the fact that they possess a negative surface charge, resulting in high colloidal steadiness in suspensions [6]. The surface charge in microalgae species mostly arises from the presence of carboxyl $(-\mathrm{COOH})$ and amine $\left(-\mathrm{NH}_{2}\right)$ groups on the cell surfaces [7].

The electric structure and colloidal behavior of microalgae cells are generally explained by the DLVO (Derjaguin, Landau, Verwey, Overbeek) theory [8]. When the total potential energy around the microalgae cells is such that the electric repulsive energy is greater than the van der waals attractive forces, stability is achieved and the microalgal particles are 
seen to be in suspension. The extent to which the electric double layer (EDL) is outstretched determines the degree of repulsion between the microalgae cells. The repulsive forces are directly proportional to the thickness of the electric double layer. As the thickness of the EDL is reduced, the zeta potential taken at the shear surface of the colloidal surfaces is reduced as well. When the absolute value of the zeta potential is reduced below roughly $20 \mathrm{mV}$, the particles will come together through Brownian motion and remain attached to each other by the van der waals forces of attraction [9], this causes rapid flocculation. When counter-charged ions are introduced to a suspension, they diffuse through the electric double layer attracting more counter ions in the vicinity of the colloidal particles, thereby shrinking the EDL. It is on this principle that conventional coagulant salts and electrocoagulation operates. In chemical coagulation, aluminum and iron salts provide the necessary ions for neutralization of the colloidal surfaces, while in electrocoagulation the coagulative agents are generated through electrolytic oxidation of the electrodes.

In its most basic form, electrocoagulation is an electrolytic technique consisting of an anode and a cathode connected to a power source, submerged in a solution containing the impurities (particles) intended for flocculation. The reaction at the anode is oxidation, while reduction of water takes place at the cathode. The cations produced at the anode interact with the negatively charged colloidal surfaces, while hydrogen gas bubbles are generated at the cathode due to the reduction of water. The hydrogen gas bubbles adhere to the produced flocs and rise to the surface of the liquid. Equations (1) and (2) show the base model of reactions that occur during electrocoagulation at the anodes and cathodes, respectively.

$$
\begin{gathered}
M \rightarrow M^{+}+e^{-} \\
\mathrm{H}_{2} \mathrm{O}+e^{-} \rightarrow \mathrm{H}_{2}+\mathrm{OH}^{-}
\end{gathered}
$$

Aside from increased efficiency and control over the flocculation process [10], Mollah et al. [11] reported the following as benefits of electrocoagulation over the conventional chemical coagulation process: less sludge, total dissolved solids (TDS), and chemical residual in the effluent; larger and more stable flocs; easy collection of flocs; less maintenance; and minimal risk of secondary pollution. It is owing to these benefits that electrocoagulation as a method of harvesting microalgae is gaining popularity in the biomass production industry.

Several variables must be known to assess the viability of a material as an electrode in the harvesting of microalgae. The material must be capable of attaining high microalgae recovery, which may be measured by the material's flocculation efficiency. In addition, microalgae are known to be susceptible to $\mathrm{pH}$ fluctuations, in many microalgae production operations, the $\mathrm{pH}$ is regulated at an optimal level, as minor variations in $\mathrm{pH}$ may allow undesired microorganisms to infiltrate the system [12]. Therefore, to maintain the purity of the culture, the electrode material employed must not have an unfavorable effect on the optimal $\mathrm{pH}$ value of the specific strain of microalgae to be harvested. Another parameter to be considered is the influence of electrode material on the temperature of the operation; this is because most microalgae require an optimal temperature of about $15^{\circ} \mathrm{C}$ to $30{ }^{\circ} \mathrm{C}$ for photosynthesis and cell division [13]. Adverse temperatures may cause heat stress, which may impair enzyme activity or cause denaturation of microalgae proteins [14,15]. As a result, the electrode material used for electrocoagulation should not induce severe thermal stress on the microalgae cells. Furthermore, to enable cost-effective electrode material selection and electrode replacement planning, the rate of electrode material consumption must be understood. Into the bargain, high levels of metal content in drinking water have been linked to the development of illnesses such as skin irritations, digestive problems, and cancers [16]. Therefore, the metal content in the effluent must be determined to identify appropriate methods for treatment and safe disposal of the effluent.

There is a lot of write-up on the use of Al and Fe electrodes in the harvesting of microalgae through electrocoagulation. Baierle et al. [17] investigated the use of spiral Al and Fe electrodes in the separation of microalgae biomass and found that Al electrodes were 
more efficient than Fe electrodes. Fayad et al. [18] studied the harvesting of Chlorella vulgaris through electrocoagulation using $\mathrm{Al}$ and Fe electrodes and found that $\mathrm{Al}$ electrodes were significantly more efficient than Fe electrodes for Chlorella vulgaris recovery. However, in comparison to the vast amount of research on $\mathrm{Al}$ and Fe electrode materials, there is limited data on the use of other electrode materials in the electrocoagulation of microalgae species.

Bleeke et al. [19] compared the flocculation efficiencies of microalgae Scenedesmus using $\mathrm{Al}, \mathrm{Mg}, \mathrm{Cu}, \mathrm{Zn}$, and brass electrode materials. The conclusion of their study favored the use of $\mathrm{Mg}$ electrodes citing its flocculation efficiency value of up to $90 \%$ at $9.2,12.5$, 18.5 , and $43 \mathrm{~min}$ at $10 \mathrm{~V}, 20 \mathrm{~V}, 30 \mathrm{~V}$, and $40 \mathrm{~V}$ respectively. In their study, the effect of the electrode material on the temperature of the system and metallic concentration in the effluent was not investigated. Rahmani et al. [20] studied the flocculation efficiency of microalgae Chlorella pyrenoidosa using $\mathrm{Al}, \mathrm{Fe}, \mathrm{Zn}, \mathrm{Cu}$, and carbon electrodes and found that $\mathrm{Al}$ electrodes have the highest flocculation efficiency with values of up to $95.8 \%$. Their study investigated the deposition of electrode material in the recovered biomass but did not examine metallic concentrations in the effluents. Other materials, such as graphite, have been reported to require the addition of electrolytes or chemical flocculants, such as $\mathrm{Al}_{2}\left(\mathrm{SO}_{4}\right)_{3}$ or chitosan, to achieve realistic flocculation efficiencies [21].

To the best of our knowledge, currently, no study has simultaneously examined and compared the viability of $\mathrm{Pb}, \mathrm{Mg}, \mathrm{Al}, \mathrm{Zn}$, and $\mathrm{Cu}$ electrodes in the harvesting of microalgaebased on the effect of voltage on the material, flocculation efficiency, $\mathrm{pH}$, temperature, electrode material consumption, and metallic content in the effluent. The simultaneous investigation of these factors is critical since they are interrelated, and an increase or decrease in one affects the others. It is therefore the goal of this study to assess the viability of $\mathrm{Pb}, \mathrm{Mg}, \mathrm{Al}, \mathrm{Zn}$, and $\mathrm{Cu}$ as electrode materials in the harvesting of microalgae, simultaneously focusing on all of the aforementioned factors.

\section{Materials and Methods}

\subsection{Microalgae Cultivation}

Chlorella vulgaris species purchased from the Korean Collection for Type Cultures (KCTC No. AG10032) were cultured in a 6 L column-type photobioreactor using BG-11 as a growth medium. As the reactor was operated in non-isolated conditions, Chlorella vulgaris could not be regarded as the only species in the reactor, but it appeared to be the dominant species. The growth medium was renewed every 6 days to prevent the growth of micro-organic contaminants and to ensure a constant supply of nutrients to the microalgal cells. The batch reactor was operated at $20^{\circ} \mathrm{C}$ and continuous aeration was supplied to the culture through high-efficiency particulate air filter aeration tubes. The optical density of the microalgae species in the reactor was monitored every two days during operation.

\subsection{Electrode Preparation}

$\mathrm{Pb}, \mathrm{Mg}, \mathrm{Al}, \mathrm{Zn}$, and $\mathrm{Cu}$ electrode plates all of the same length $(10 \mathrm{~cm})$ and width $(2 \mathrm{~cm})$, with a surface area of $20 \mathrm{~cm}^{2}$ on each side, were weighed on an analytical and precision balance (Sartorius BS/BT electronic) and their initial weights recorded. Each material consisted of three sets of electrodes in groups of two, which were labeled as $10 \mathrm{~V}$, $20 \mathrm{~V}$, and $30 \mathrm{~V}$, with each group having an anode and a cathode. The initial weights of the electrodes were found to be $45 \pm 3 \mathrm{~g}$ for $\mathrm{Pb}, 3.4 \pm 0.2 \mathrm{~g}$ for $\mathrm{Mg}, 1.6 \pm 0.2 \mathrm{~g}$ for Al, $4.3 \pm 0.1 \mathrm{~g}$ for $\mathrm{Zn}$, and $5.1 \pm 0.2 \mathrm{~g}$ for Cu electrodes.

\subsection{Electrocoagulation Experiments}

For each electrode material, $450 \mathrm{~mL}$ algae suspension was poured in three $500 \mathrm{~mL}$ capacity beakers labeled as $10 \mathrm{~V}, 20 \mathrm{~V}$, and $30 \mathrm{~V}$. The anodes and cathodes separated by a distance of $4 \mathrm{~cm}$ were then placed upright in the suspensions. The submerged length of the electrodes was found to be $7.5 \mathrm{~cm}$ resulting in an effective area of $30 \mathrm{~cm}^{2}$ for each electrode. The anode and cathodes were connected to the positive and negative terminals of a DC power supply (Toyotech dp30-03 DC) respectively. The beaker was then placed on 
a magnetic stirrer and the suspension was gently mixed at $20 \mathrm{rpm}$. The voltage, adjusted to $10 \mathrm{~V}, 20 \mathrm{~V}$, and $30 \mathrm{~V}$ for each electrode, was applied for $20 \mathrm{~min} .5 \mathrm{~mL}$ aliquots of the samples were taken from each beaker at two minutes intervals during the flocculation process. After electrocoagulation reaction for $20 \mathrm{~min}$, the electrodes were carefully cleaned with deionized distilled water and dried overnight in an incubator at $50{ }^{\circ} \mathrm{C}$ before being placed in a desiccator and measuring their final weights. Figure 1 shows a diagram depicting the experimental setup of the electrocoagulation process.

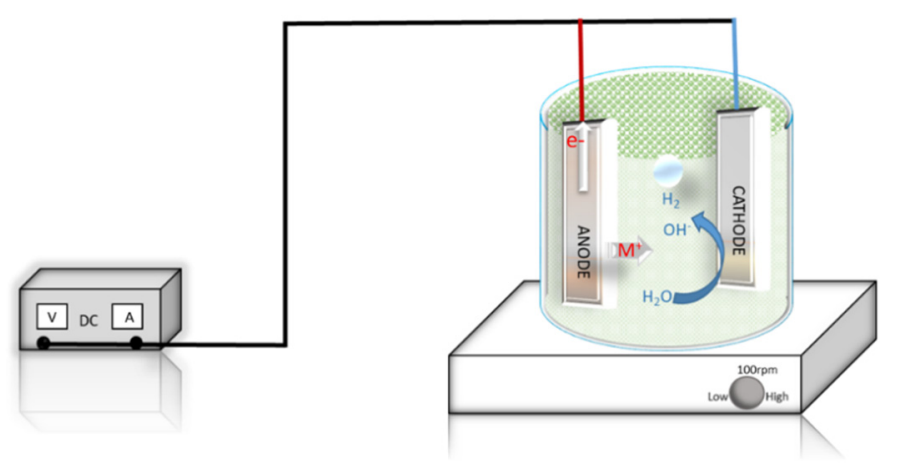

Figure 1. Experimental setup of the electrocoagulation process.

\subsection{Analytical Methods}

The $\mathrm{pH}$ of the samples was measured using a $\mathrm{pH}$ meter (laquatwin-pH-11). The optical density (OD) of the microalgae species was monitored by measuring the absorbance of taken samples at $700 \mathrm{~nm}$ wavelength using an ultra-violet spectrometer (Thermo Scientific ${ }^{\mathrm{TM}}$ Evolution $^{\mathrm{TM}}$ 60S UV-Visible, Massachusetts, U.S.A). The flocculation efficiency (FE) of each sample was calculated as a percentage using Equation (3):

$$
F E=\left(\frac{O D_{i}-O D_{t}}{O D_{t}}\right) \times 100,
$$

where $O D_{i}$ and $O D_{t}$ are the optical density at beginning of flocculation and at time $t$, respectively.

After the samples were filtered through a $0.2 \mu \mathrm{m}$ membrane filter (cellulose nitrate membrane, Whatman) and acidified with $1 \mathrm{~mL}$ of $1 \mathrm{~N}$ nitric acid to keep the metals dissolved, the metal content of the supernatants was determined using an inductively coupled plasma (ICP, Optima 2100DV, PerkinElmer, Hägersten, Sweden).

Except for microalgae cultivation, all experiments were performed in duplicate.

\section{Results and Discussion}

\subsection{Flocculation Efficiency (FE)}

Figure 2 depicts the findings of FE (\%) against time during the experiment. For all electrode materials, higher FE values were obtained at shorter periods with a higher voltage. This was because the rate of electrolytic oxidation increased, giving rise to an abundant supply of ions at higher voltages, increasing contact between the metal ions and the negatively charged algal surfaces. As the ionic strength of the solution increased, the thickness of the EDL decreased, which in turn reduced the zeta potential. Consequently, this increased the rate of surface charge neutralization, ultimately resulting in higher rates of flocculation. These cations are said to further change into monomeric and polymeric coagulant species and later on, to amorphous metal hydroxides [22]. Similar results showing the relationship between voltage and flocculation efficiency were reported by Bleeke et al. [19]. 

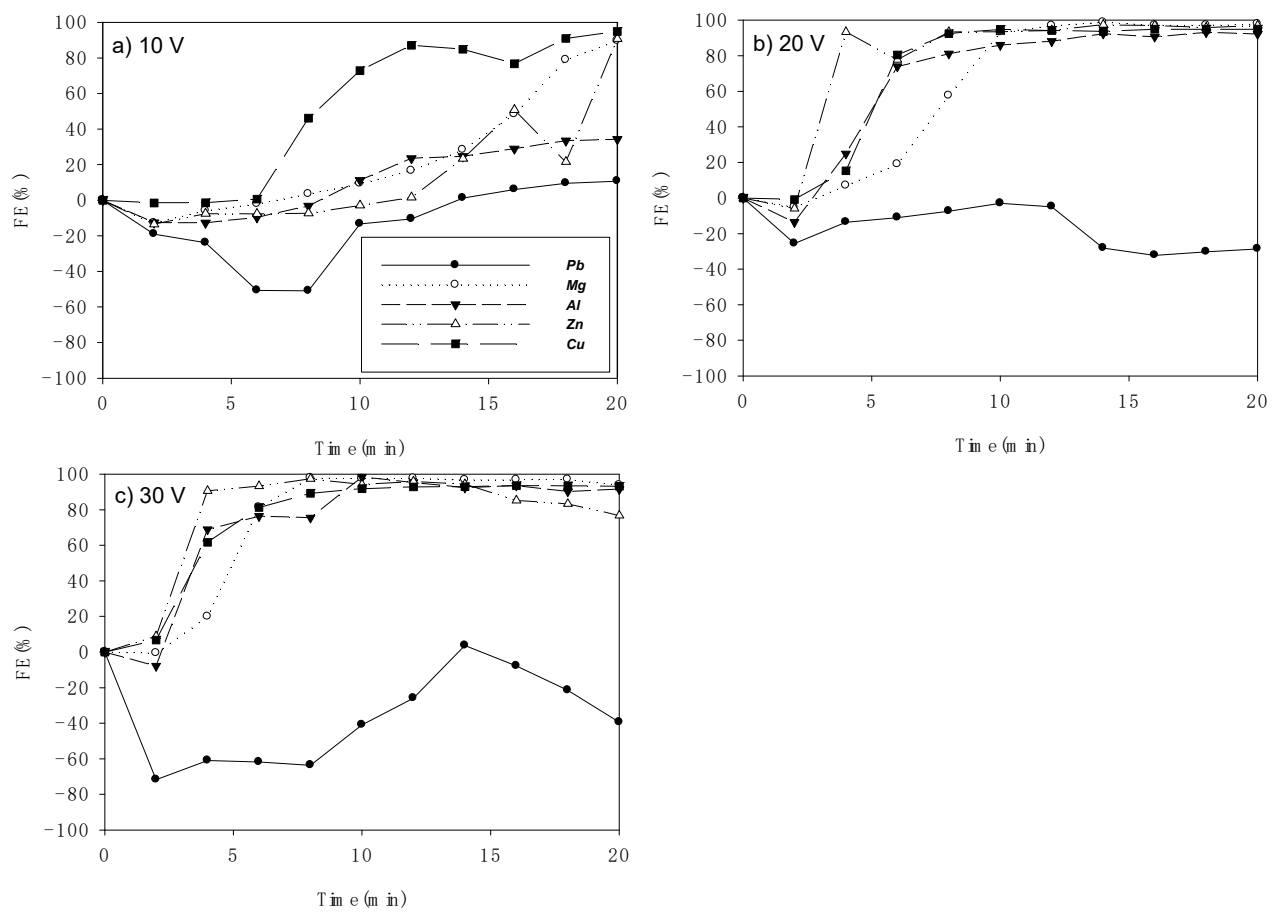

Figure 2. Effect of voltage on the flocculation efficiency of $\mathrm{Pb}, \mathrm{Mg}, \mathrm{Al}, \mathrm{Zn}$, and $\mathrm{Cu}$ electrodes at (a) $10 \mathrm{~V}$, (b) $20 \mathrm{~V}$, and (c) $30 \mathrm{~V}$.

Table 1 shows the optimum FE values and their corresponding time in minutes during electrocoagulation. All electrode materials, except for those at $10 \mathrm{~V}$, attained their potential optimal FE values over the experimentation period. The optimum FE values were divided by their corresponding periods to establish the order of flocculation efficiency among the electrode materials. From highest to lowest, the order was found to be $\mathrm{Cu}, \mathrm{Zn}, \mathrm{Mg}, \mathrm{Al}$, and $\mathrm{Pb}$ at $10 \mathrm{~V} ; \mathrm{Mg}, \mathrm{Zn}, \mathrm{Cu}, \mathrm{Al}$, and $\mathrm{Pb}$ at $20 \mathrm{~V}$; and $\mathrm{Mg}, \mathrm{Zn}, \mathrm{Al}, \mathrm{Cu}$, and $\mathrm{Pb}$ at $30 \mathrm{~V}$. It was observed that at $10 \mathrm{~V}$ and $20 \mathrm{~V}, \mathrm{Mg}, \mathrm{Zn}$, and $\mathrm{Cu}$ electrodes outperformed the traditionally used $\mathrm{Al}$ electrodes. In addition to higher $\mathrm{FE}$ values, another benefit of using $\mathrm{Mg}, \mathrm{Zn}$, or $\mathrm{Cu}$ electrodes over $\mathrm{Al}$ electrodes is that they are less harmful to human beings and the environment. For example, the quality standards for drinking water in this study's location (South Korea) require less than $1 \mathrm{mg} / \mathrm{L}$ for $\mathrm{Cu}$, less than $3 \mathrm{mg} / \mathrm{L}$ for $\mathrm{Zn}$, and there is no limit for $\mathrm{Mg}$. In comparison, Korean legislation prohibits the presence of as little as $0.2 \mathrm{mg} / \mathrm{L}$ of $\mathrm{Al}$ in drinking water [23].

Table 1. Maximum FE (FE $\mathrm{Fax}_{\text {ax }}$ values and their corresponding time during electrocoagulation.

\begin{tabular}{ccccccccccc}
\hline \multirow{2}{*}{$\begin{array}{c}\text { Voltage } \\
(\mathbf{V})\end{array}$} & $\begin{array}{c}\mathbf{F E}_{\max } \\
\mathbf{( \% )}\end{array}$ & $\begin{array}{c}\text { Time } \\
(\mathbf{m i n})\end{array}$ & $\begin{array}{c}\mathbf{F E}_{\max } \\
\mathbf{( \% )}\end{array}$ & $\begin{array}{c}\text { Time } \\
(\mathbf{m i n})\end{array}$ & $\begin{array}{c}\mathbf{F E}_{\max } \\
\mathbf{( \% )}\end{array}$ & $\begin{array}{c}\text { Time } \\
(\mathbf{m i n})\end{array}$ & $\begin{array}{c}\mathbf{F E}_{\max } \\
\mathbf{( \% )}\end{array}$ & $\begin{array}{c}\text { Time } \\
(\mathbf{m i n})\end{array}$ & $\begin{array}{c}\mathbf{F E}_{\max } \\
(\mathbf{\%})\end{array}$ & $\begin{array}{c}\text { Time } \\
(\mathbf{m i n})\end{array}$ \\
\hline 10 & 10.7 & 20 & 89.6 & 20 & 66.4 & 20 & 90.6 & 20 & 94.9 & 20 \\
20 & -3.0 & 10 & 98.7 & 14 & 93.0 & 18 & 97.4 & 14 & 94.9 & 16 \\
30 & 3.7 & 14 & 97.8 & 8 & 98.4 & 10 & 97.3 & 8 & 93.6 & 16 \\
\hline
\end{tabular}

Table 2 shows the final FE values after 20 min of electrocoagulation. Except for the experiments at $10 \mathrm{~V}$, the clarity of the supernatants began to decrease after optimal FE. This was due to the precipitation of excess insoluble amorphous metal hydroxides after the majority of the algae had already been flocculated and risen to the surface. 
Table 2. FE values after 20 min of electrocoagulation.

\begin{tabular}{cccccc}
\hline \multirow{2}{*}{ Voltage (V) } & \multicolumn{5}{c}{ FE Values (\%) } \\
\cline { 2 - 6 } & $\mathbf{P b}$ & $\mathbf{M g}$ & $\mathbf{A l}$ & $\mathbf{Z n}$ & $\mathbf{C u}$ \\
\hline 10 & 10.7 & 89.6 & 66.4 & 90.6 & 94.9 \\
20 & -28.6 & 97.8 & 92.1 & 96.9 & 94.9 \\
30 & -39.4 & 93.7 & 91.5 & 76.7 & 93.2 \\
\hline
\end{tabular}

Since floc formation is a cation-dependent activity, it was expected before the experiments that at all voltages, $\mathrm{Mg}$ electrodes would achieve the highest $\mathrm{FE}$, followed by $\mathrm{Al}$, $\mathrm{Zn}, \mathrm{Pb}$, and lastly $\mathrm{Cu}$ electrodes as per the standard redox potential chart [24]. Rather, the findings of this study, as seen in the tables above, show variations. The following paragraphs will discuss the potential causes of the difference between the anticipated and achieved outcomes.

The insoluble metal hydroxides precipitated during the electrocoagulation process altered the visibility of the suspension, consequently interfering with the optical density measurements. This was especially evident in the case of $\mathrm{Pb}$, in which the microalgae species had unmistakably flocculated and risen to the surface, but the suspension became thick and cloudy affecting the absorbance of the supernatant. As can be seen in Figure 2, $\mathrm{Pb}$ electrodes appear to have achieved minimal to no flocculation at all voltages and yet a look at Figure 3 shows otherwise.

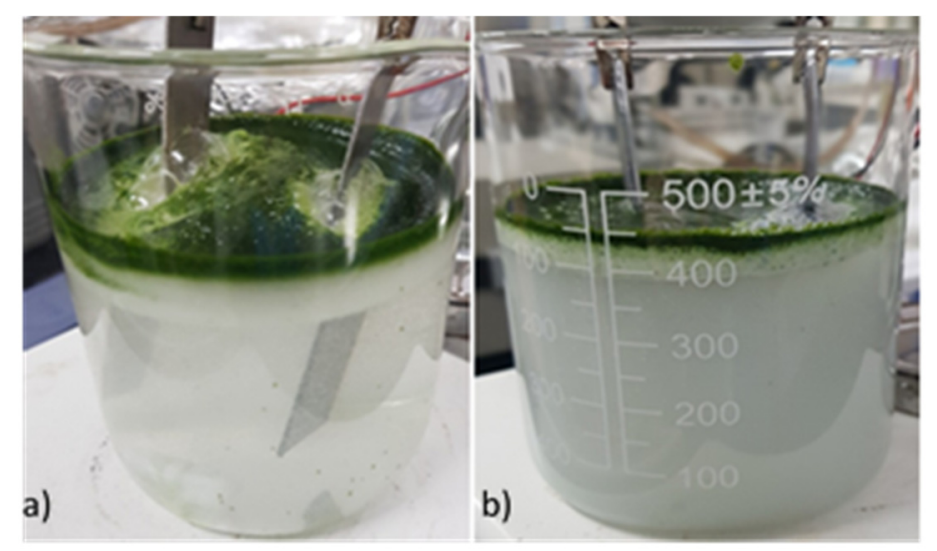

Figure 3. Comparison in visibility of the supernatant after electrocoagulation with (a) $\mathrm{Mg}$ and (b) $\mathrm{Pb}$ electrodes.

Furthermore, as previously stated, the rise of the floc to the surface is caused by the evolution of hydrogen at the negatively polarized cathode. As a result, even if an electrode has a high electrolytic oxidation potential, if the material's characteristics are not conducive to bubble nucleation, FE results may be observed to be lower than expected.

In accordance to Rayleigh's work [25], Equation (4) shows that when diameter $(d)$ is a linear function of time $(t), \mathrm{K}$ is the Henry constant, $\delta \mathrm{C}$ is the degree of super saturation of dissolved gas, and $\rho$ is the electrolytic density:

$$
d(t)=\left(\frac{2 K \delta C}{3 \rho}\right)^{0.5} t
$$

Bubbles ranging in size between 17 and $60 \mu \mathrm{m}$ form at the cathodes [26]. These bubbles tend to be bigger at larger contact angles and on hydrophilic surfaces while being smaller at small contact angles and hydrophobic surfaces [27]. Once the surface tension that is keeping the bubble attached to the cathode becomes equal to the buoyancy acting perpendicular to the bubble, detachment occurs [28]. As can be seen in Figure 2, at the beginning of the experiments, slight negative FE values were recorded. A possible explanation for 
these negative values is that in the early stages of the experiments, floc formation in the bulk solution had taken place faster than bubble detachment at the cathodes, subsequently thickening the algae suspension. This thickened suspension recorded higher optical density values than the initial values of the untampered algae suspension. After some time, the bubbles begun to detach from the electrodes, carrying with them the floc to the surface, and the suspension begun to clear. Figure 2 shows that $\mathrm{Cu}$ electrodes recorded the least early negative $\mathrm{FE}$ values, followed by $\mathrm{Zn}, \mathrm{Mg}$, and $\mathrm{Al}$, and $\mathrm{Pb}$ electrodes had the longest early negative FE phase. The shorter negative FE of $\mathrm{Cu}$ electrodes suggests that in the early stages of the experiment, floc formation with $\mathrm{Cu}$ electrodes had either taken place at a slower rate than the other electrodes or the bubble nucleation rate and bubble detachment at the cathodes of $\mathrm{Cu}$ electrodes occurred relatively faster than the other electrodes studied. Assuming the latter to be true, then to enhance floc floatation and minimize recovery time, $\mathrm{Cu}$ electrodes may be employed as cathodes coupled with anodes of other electrode materials. Further research is required to draw a clear conclusion on this assumption.

Figure 4 shows the periodic FE calculated within 2 min intervals. Here, instead of repeatedly using the optical density of the suspension before the start of the experiment as our $O D_{i}$ in Equation (3), $O D_{i}$ was constantly substituted with the optical density 2 min before $O D_{t}$. Rather than the relatively steady rise with smoother curves observed in Figure 2, the results showed a much-pronounced zigzag pattern, thus implying an intermittent rise and fall in coagulation activity. In support of this observation, Fekete et al. [29] reported that "the released metal ions are only active as coagulants briefly after their formation and should therefore be intermixed as fast as possible".
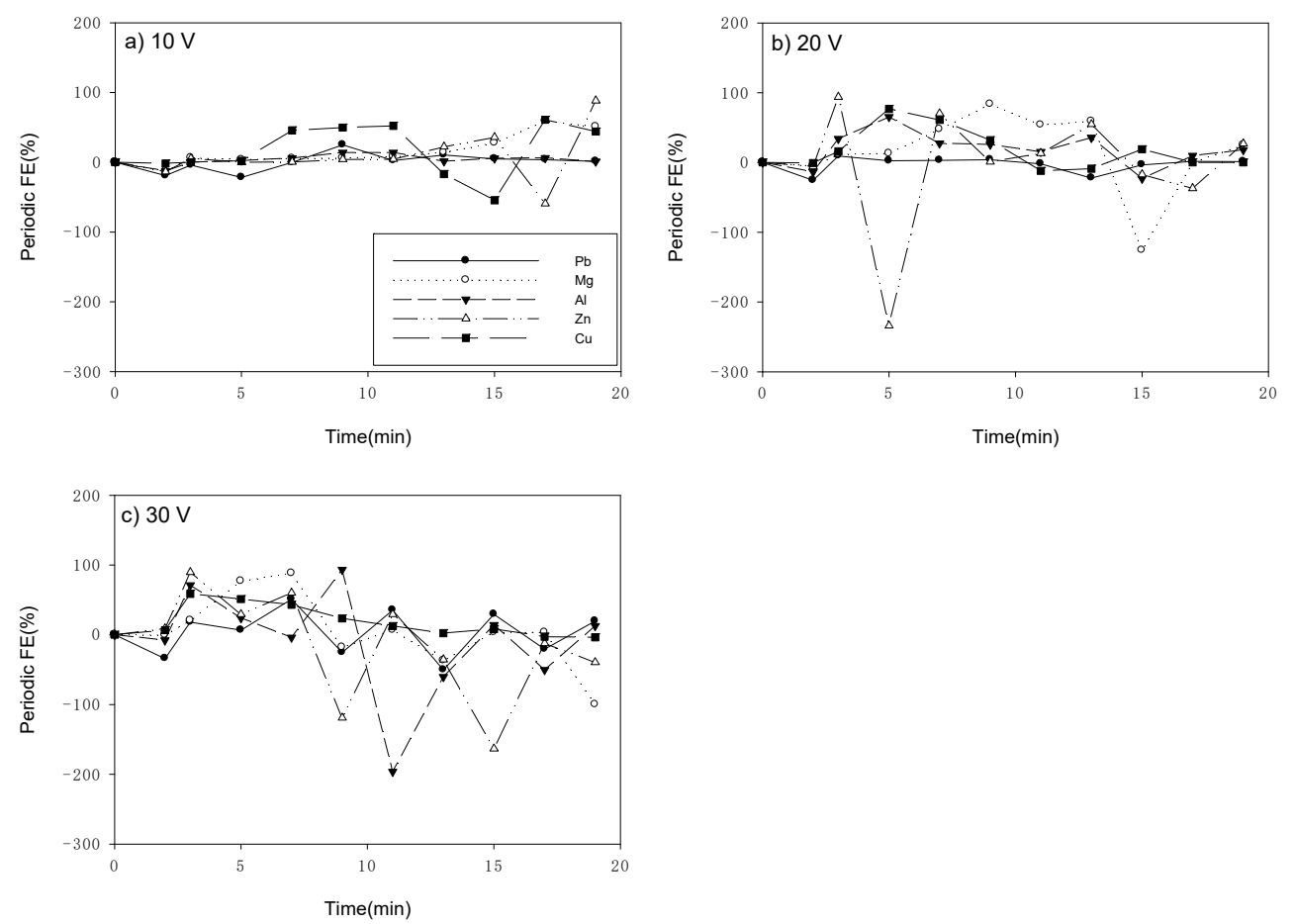

Figure 4. Periodic FE (\%) with 2 min intervals for $\mathrm{Pb}, \mathrm{Mg}, \mathrm{Al}, \mathrm{Zn}$, and $\mathrm{Cu}$ electrodes at (a) $10 \mathrm{~V}$, (b) $20 \mathrm{~V}$, and (c) $30 \mathrm{~V}$.

In Table 3, a brief overview of recent studies on electrodes other than $\mathrm{Al}$ or Fe utilized in the electrocoagulation of microalgae is compared. In these studies, volume, initial biomass concentration, number of electrodes, the effective surface area of the electrodes, and the distance between the electrode materials were all noted as factors that influenced FE. In addition, it can be noticed from the table that $\mathrm{Al}$ coupled with other additives, such as sand or with cathodes of other metals, is still the most studied electrode material. 
Table 3. An overview of recent studies on electrodes other than $\mathrm{Al}$ or Fe utilized for microalgae harvesting.

\begin{tabular}{ccccc}
\hline Species & Material & Time (min) & FE (\%) & Reference \\
\hline $\begin{array}{c}\text { Phaeodactylum } \\
\text { tricornutum }\end{array}$ & $\begin{array}{c}\mathrm{Al} / \mathrm{Fe} \text { (anode) and } \\
\mathrm{IrO}_{2} / \mathrm{TiO}_{2} \text { (cathode) } \\
\mathrm{Al} / \mathrm{Fe}(\text { anode) and } \\
\mathrm{IrO}_{2} / \mathrm{TiO}_{2} \text { (cathode) }\end{array}$ & 30 & 94 & {$[30]$} \\
Chlorella vulgaris & 25 & 98 & {$[30]$} \\
Scenedesmus & $\mathrm{Al}, \mathrm{Zn}, \mathrm{Mg}, \mathrm{Fe}, \mathrm{Cu}$ and Brass & $7.3-71.1$ & 90 & {$[19]$} \\
acuminatus & $\mathrm{Al}$ coupled with sand & 4.5 & 98 & {$[31]$} \\
Dunaliella salina & Graphite mixed with chitosan & 4 & 96 & {$[32]$} \\
Chlorella sp. 0217 & $\mathrm{Al}, \mathrm{Zn}, \mathrm{Fe}, \mathrm{Cu}$ and carbon & 5 & $71-96$ & {$[20]$} \\
Chlorella pyrenoidosa & $\mathrm{Al}$ and $\mathrm{Cu}$ & 25 & 95 and 85 & {$[33]$} \\
Chlorella vulgaris & & & &
\end{tabular}

\subsection{Temperature}

Figure 5 shows the results of temperature against time obtained throughout the experiment. As expected, in respect to ohms law, the supernatant from the experiments carried out at $30 \mathrm{~V}$ recorded the highest rise in temperature while those at $10 \mathrm{~V}$ recorded the lowest change in temperature.
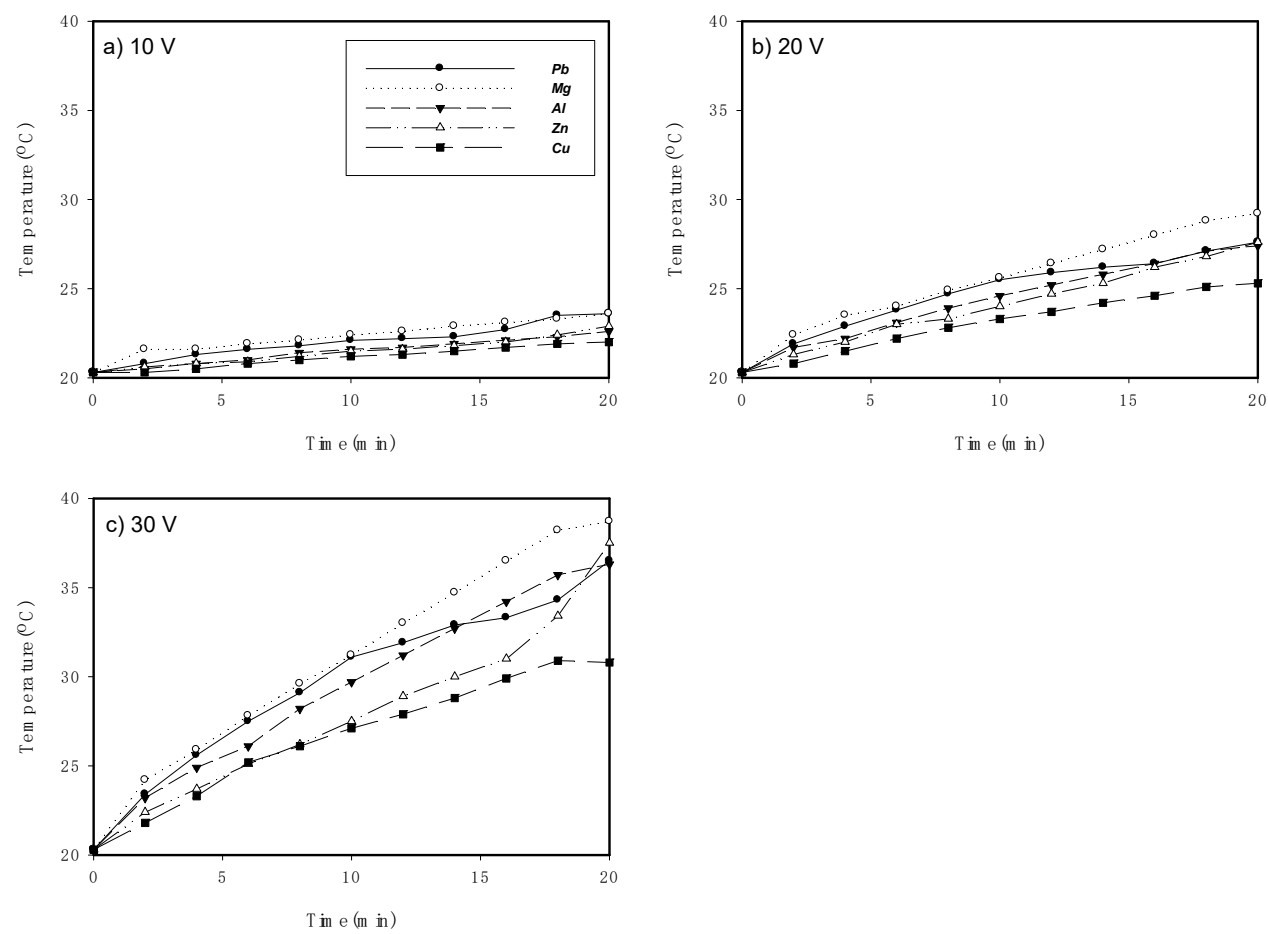

Figure 5. Temperature changes in the supernatants during electrocoagulation at (a) $10 \mathrm{~V},(\mathbf{b}) 20 \mathrm{~V}$, and (c) $30 \mathrm{~V}$.

Calculations were performed according to joules law of heating in Equation (5),

$$
Q=I^{2} R T
$$

where $Q$ is the amount of heat produced by a conductor, $I$ is the electric current in amperes, $R$ is the resistance, and $T$ is the time in seconds. The theory-based results showed that under the same conditions, $\mathrm{Pb}$ electrodes would produce the most heat, followed by $\mathrm{Zn}$, $\mathrm{Mg}$, and $\mathrm{Al}$, and $\mathrm{Cu}$ electrodes would produce the lowest amount of heat. However, the results obtained from the experiments showed $\mathrm{Mg}$ electrodes recording the highest values followed by $\mathrm{Pb}, \mathrm{Al}$, and $\mathrm{Zn}$, and $\mathrm{Cu}$ electrodes recorded the lowest change in temperature. 
To explain this contrast in theoretic and experimental results, it was proposed that corrosion of the anodes and passivation of the cathodes interfered with the resistance of the initial electrode materials thus altering the amount of heat produced. For example, $\mathrm{Mg}$ and $\mathrm{MgO}$ have a resistance of $4.45 \times 10^{-8}$ and $10^{-8} \Omega \mathrm{m}$, respectively [34]. Figure 6 shows images of the anodes from the experiments carried out at $30 \mathrm{~V}$ before and after electrocoagulation.

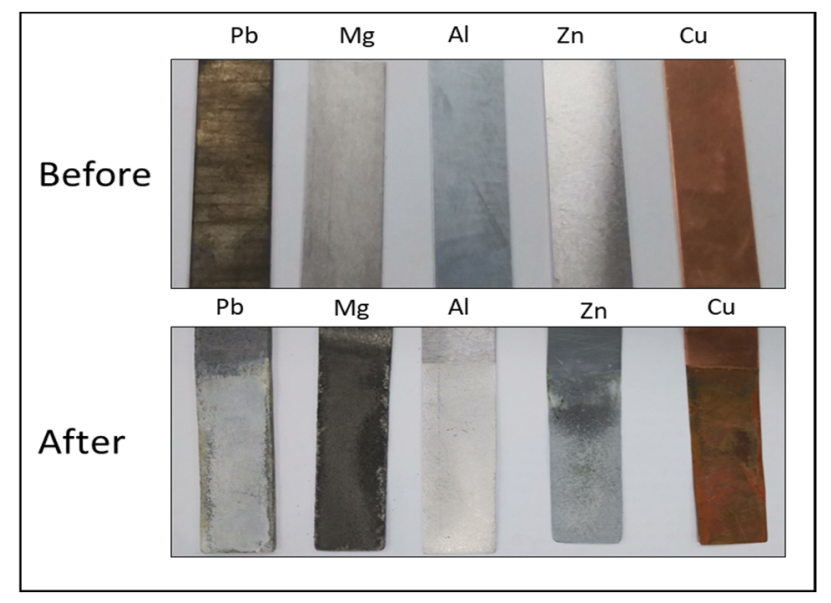

Figure 6. The anodes before and after the experiment at $30 \mathrm{~V}$ are compared.

Additionally, the size of the bubbles generated at the electrode surfaces and the duration between formation and detachment of these bubbles causes the resistance drops during the electrocoagulation process [35]. This is due to the hydrogen bubbles at the cathodes momentarily covering parts of the electrode material before detachment, therefore forming a barrier between the electrode and the electrolyte. Assuming that the size and the duration in which these temporal barriers form and disappear on the electrode surfaces are not proportional to the resistance of their respective electrode materials, the ratio difference of the ohmic drops between the electrode materials becomes different from the ratio difference of the resistance between the electrode materials. This then becomes an additional explanation as to why the supernatant's change in temperature differs from those calculated from the joules law of heating.

It is important to note that although higher temperatures increase the efficiency of electrocoagulation [36], the effect of high temperature on microalgae cells is undesirable [15]. Cu electrodes' modest temperature rise, as compared to other electrode materials, may enable its use in industry to minimize heat damage to microalgae cells.

Other parameters such as enthalpy, entropy, and heat capacity may influence the temperature of the system. In comparison to electrode material, they are primarily concerned with the electrolyte; thus, they will not be explored further as they are beyond the focus of this research.

\subsection{Consumption of Electrode Material and $p H$ Variations}

Table 4 shows the weight loss and weight gains of the electrodes following the experiments expressed as a percentage of their initial weight. The anodes of all the electrode materials experienced a net weight loss directly proportional to the voltage.

These results are in accordance with Faraday's law of electrolysis that predicts weight loss at the anodes. The average weight loss in percentage form was attained with $\mathrm{Zn}, \mathrm{Al}$, $\mathrm{Cu}, \mathrm{Pb}$, and $\mathrm{Mg}$ electrodes in order from highest to lowest.

Figure 7 shows a relationship between the experimental results of the weight loss at the anode at a specific voltage and the theoretic yields as predicated by Faraday's law at that voltage, calculated using Equation (6):

$$
w=\frac{i t M}{Z F}
$$


where $w$ is the metal dissolving in grams, $i$ is the current in (amperes), $t$ is the time in (seconds), $M$ is the molecular weight of the electrode material, $\mathrm{Z}$ is the oxidation number of the electrode material, and $F$ is Faraday's constant $(96,485 \mathrm{C} / \mathrm{mol})$.

Table 4. Weight loss/gain at the anodes and cathodes after electrocoagulation.

\begin{tabular}{ccccccc}
\hline \multirow{2}{*}{$\begin{array}{c}\text { Electrode } \\
\text { Material }\end{array}$} & \multicolumn{2}{c}{ Weight Loss/Gain at Anodes (\%) } & \multicolumn{3}{c}{ Weight Loss/Gain at Cathodes (\%) } \\
\cline { 2 - 7 } & $\mathbf{1 0} \mathbf{~ V}$ & $\mathbf{2 0 ~ V}$ & $\mathbf{3 0 ~ V}$ & $\mathbf{1 0 ~ V}$ & $\mathbf{2 0 ~ V}$ & $\mathbf{3 0 ~ V}$ \\
\hline $\mathrm{Pb}$ & -1.004 & -2.345 & -3.855 & -0.002 & -0.004 & -0.001 \\
$\mathrm{Mg}$ & -0.506 & -1.708 & -3.435 & -0.010 & -0.011 & +0.003 \\
$\mathrm{Al}$ & -1.851 & -5.215 & -9.070 & -0.244 & -0.651 & -1.195 \\
$\mathrm{Zn}$ & -1.810 & -6.759 & -11.043 & +0.143 & +0.011 & -0.120 \\
$\mathrm{Cu}$ & -1.873 & -3.733 & -6.069 & -0.005 & -0.006 & -0.004 \\
\hline
\end{tabular}

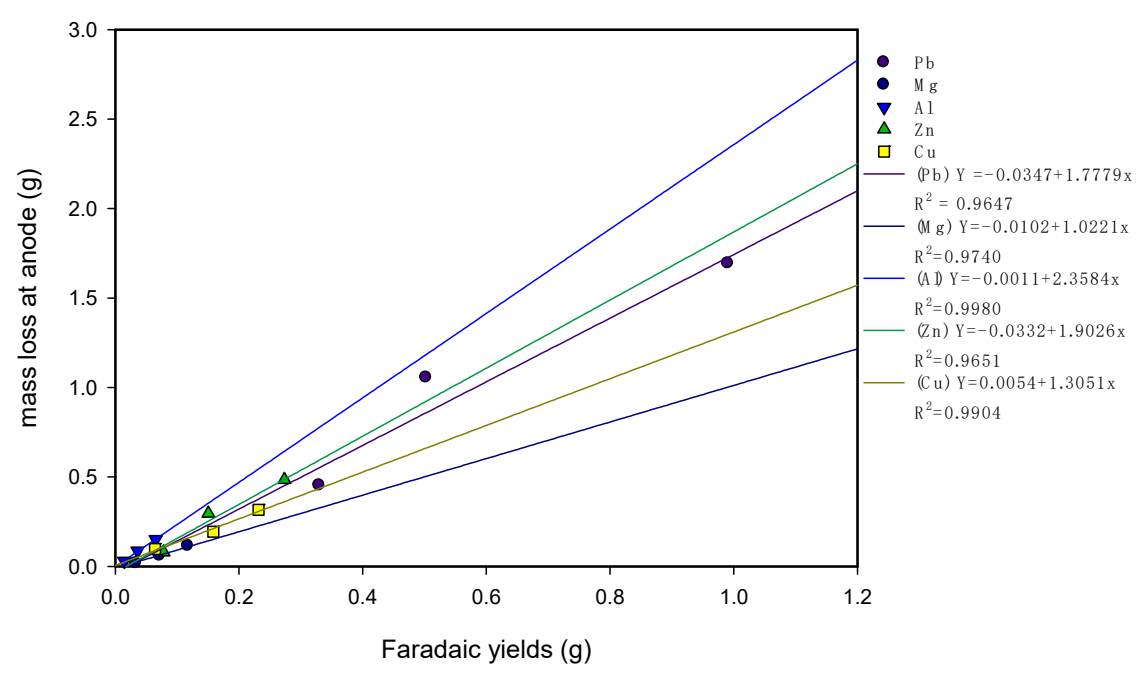

Figure 7. Relationship between the predicted faradaic weight loss at the anodes and the experimental weight loss.

For all electrode materials, the weight loss of the anodes was found to be higher than predicted by Faraday's law. Cañizares et al. [37] reported that chemical dissolution at the anodes adds to electrochemical dissolution, therefore resulting in higher weight loss. Fekete et al. [29] conducted electrocoagulation experiments on aluminum electrodes in which they filtered the effluent from the vicinity of the anodes and examined the residual under X-ray fluorescence (XRF) measurements. The residual showed grains of Al electrodes and they attributed these grains to inter-granular corrosion of the anodes. Based on the findings of the preceding authors, it is inferred that the increased weight loss at the anodes was due to chemical dissolution and inter-granular corrosion of the anodes.

The reduction of $\mathrm{H}_{2} \mathrm{O}$ to $\mathrm{H}_{2}$ and $\mathrm{OH}^{-}$ions at the cathodes rendered the solution locally alkaline [29], allowing for a degree of chemical dissolution of the cathodes [38], which is otherwise not attainable in neutral aqueous solutions due to the protective layer that may exist on the electrodes. From the results in Table 4, chemical dissolution is minimal for all but $\mathrm{Al}$ cathodes.

Figure 8 shows the variations in $\mathrm{pH}$ during the experiment. Samples from the experiments carried out with $\mathrm{Pb}$ electrodes recorded the highest $\mathrm{pH}$ values, followed by $\mathrm{Mg}, \mathrm{Zn}$, and $\mathrm{Cu}$, and $\mathrm{Al}$ recorded the lowest $\mathrm{pH}$ variations. An increase in voltage resulted in a reasonable increase in $\mathrm{pH}$ for all but $\mathrm{Al}$ electrode materials. It is believed that the $\mathrm{Al}(\mathrm{OH})_{3}$ protective layer on $\mathrm{Al}$ cathodes being amphoteric acted as a Lewis acid and bound some of the $\mathrm{OH}^{-}$ions from the reduction of water to produce $\mathrm{Al}(\mathrm{OH})_{4}{ }^{-}$, hence the lower increase in $\mathrm{pH}$ values and the relatively higher chemical dissolution rates for experiments with aluminum electrodes. 

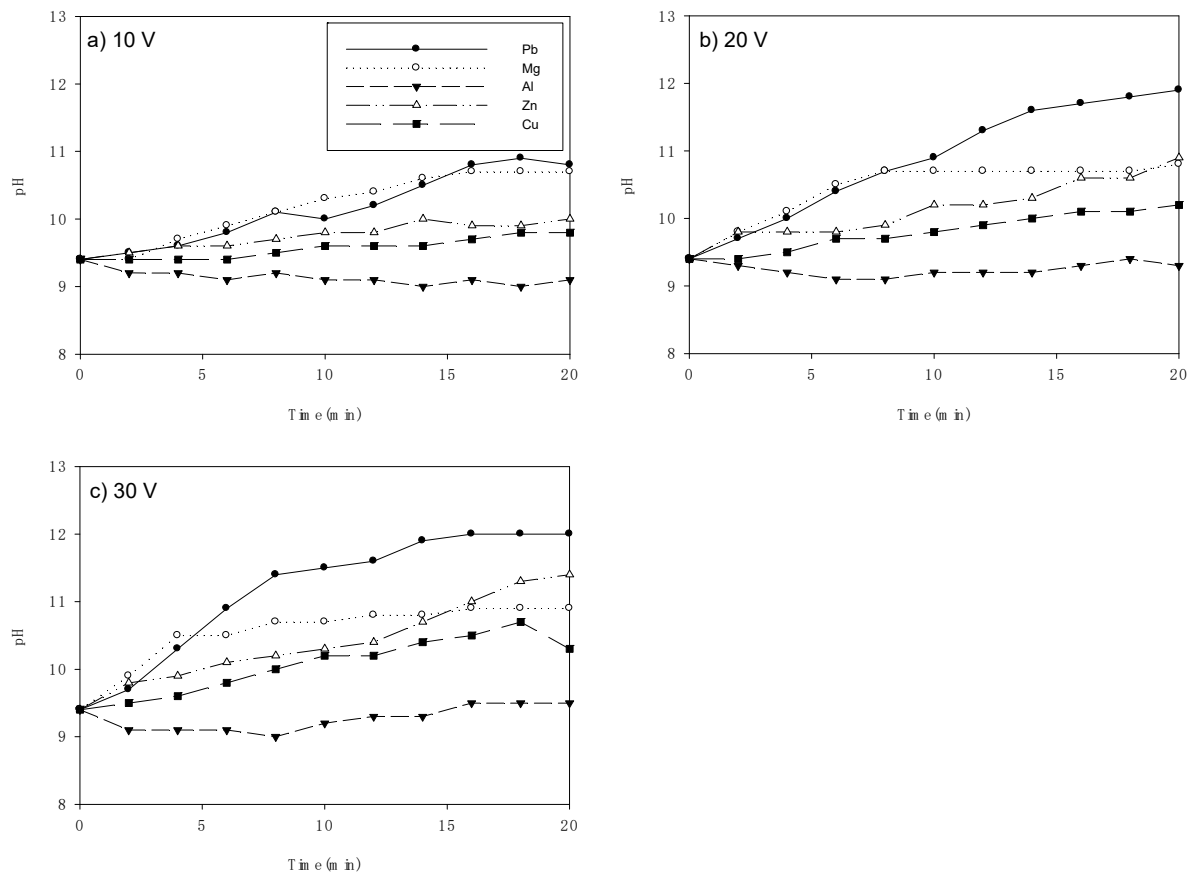

Figure 8. Effect of voltage and electrode material on the $\mathrm{pH}$ of the supernatant during electrocoagulation at (a) $10 \mathrm{~V}$, (b) $20 \mathrm{~V}$, and (c) $30 \mathrm{~V}$.

\subsection{Metallic Content in the Effluents after Electrocoagulation}

Laws governing the permissible discharge metal concentrations in effluent disposal vary by location and region; thus, it is critical to understand the metal content of the final effluent before deciding on the type of electrode material to utilize in the EC process. Here, the results of metallic concentration in $\mathrm{mg} / \mathrm{L}$ obtained following an ICP examination after 20 min of electrocoagulation are shown in Table 5.

Table 5. Metallic concentrations in the effluent after microalgae recovery $(\mathrm{mg} / \mathrm{L})$.

\begin{tabular}{cccc}
\hline Electrode Material & $\mathbf{1 0} \mathbf{~ V}$ & $\mathbf{2 0 ~ V}$ & $\mathbf{3 0 ~ V}$ \\
\hline $\mathrm{Pb}$ & 0.513 & 3.462 & 43.835 \\
$\mathrm{Mg}$ & 20.535 & 7.015 & - \\
$\mathrm{Al}$ & 1.336 & 4.563 & 9.087 \\
$\mathrm{Zn}$ & 0.089 & 0.079 & 0.081 \\
$\mathrm{Cu}$ & 0.434 & 0.363 & 0.252 \\
\hline
\end{tabular}

\subsection{Practical Implications of This Study}

The findings of this study show that $\mathrm{Pb}, \mathrm{Mg}, \mathrm{Zn}$, and $\mathrm{Cu}$ electrodes can be applied as electrode materials in the electrocoagulation of microalgae.

$\mathrm{Mg}, \mathrm{Zn}$, and $\mathrm{Cu}$ electrodes showed higher $\mathrm{FE}$ values than the traditional $\mathrm{Al}$ electrode materials; an additional benefit of utilizing these metals as electrode materials is that they are less toxic than the $\mathrm{Al}$.

Although $\mathrm{Pb}$ is capable of achieving flocculation, its high toxicity must be considered when it is chosen as an electrode material.

The considerably shorter negative FE values with $\mathrm{Cu}$ electrodes in the early stages of the experiment are emphasized for future studies that may include $\mathrm{Cu}$ cathodes coupled with anodes of different materials to improve microalgae floc flotation.

All electrode materials showed metallic concentrations in the final effluents; however, this was not considered as the total metal discharge, as adsorption of the metals on the microalgae surfaces is suspected to have occurred. Therefore, to prevent additional 
metal discharge or precipitation in the system, the electrocoagulation process should be discontinued after optimal amounts of microalgae have been collected.

\section{Conclusions}

In this study, $\mathrm{Pb}, \mathrm{Mg}, \mathrm{Al}, \mathrm{Zn}$, and $\mathrm{Cu}$ were examined to compare and assess the appropriateness of each electrode material in microalgae harvesting. The influence of voltage on the electrode materials was studied, and parameters such as FE, temperature, $\mathrm{pH}$, material consumption, and metallic concentration in the effluent were investigated. Based on the experimental results, the following conclusions were drawn.

- In addition to $\mathrm{Al}$ electrodes, $\mathrm{Pb}, \mathrm{Mg}, \mathrm{Zn}$, and $\mathrm{Cu}$ electrodes can be used as electrode materials in the harvesting of microalgae.

- Higher voltages increase the flocculation efficiency of microalgae as well as the $\mathrm{pH}$ of the supernatants, temperature, and consumption of the electrode materials.

- Other variables such as the rate of metal passivation, corrosion, bubble nucleation, and the electrode material's affinity for water contribute to the determination of a material's viability as an electrode in the harvesting of microalgae.

- $\mathrm{Pb}$ is not an appropriate electrode material to employ in the harvesting of microalgae when the clarity of the supernatant (effluent) is crucial.

- All the electrode materials showed metallic concentrations in their effluents.

Author Contributions: Conceptualization, J.T.P. and S.O.; methodology J.T.P., H.P., and J.W.; data analysis J.T.P. and S.O.; writing-original draft preparation, J.T.P.; writing-review and editing, J.T.P. and S.O.; supervision, S.O. All authors have read and agreed to the published version of the manuscript.

Funding: This research was funded by Korea Research Foundation (NRF-2018R1D1A1B07049783).

Institutional Review Board Statement: Not applicable.

Informed Consent Statement: Not applicable.

Data Availability Statement: Not applicable.

Acknowledgments: The authors are grateful to Kyungpook National University for supporting this research.

Conflicts of Interest: The authors declare no conflict of interest.

\section{References}

1. Milano, J.; Ong, H.C.; Masjuki, H.H.; Chong, W.T.; Lam, M.K.; Loh, P.K.; Vellayan, V. Microalgae Biofuels as an Alternative to Fossil Fuel for Power Generation. Renew. Sustain. Energy Rev. 2016, 58, 180-197. [CrossRef]

2. Vale, M.A.; Ferreira, A.; Pires, J.C.M.; Gonçalves, A.L. CO2 capture using microalgae. Adv. Carbon Capture 2020, $381-405$.

3. Sun, H.; Zhao, W.; Mao, X.; Li, Y.; Wu, T.; Chen, F. High-Value Biomass from Microalgae Production Platforms: Strategies and Progress Based on Carbon Metabolism and Energy Conversion. Biotechnol. Biofuels 2018, 11, 227. [CrossRef] [PubMed]

4. Randrianarison, G.; Ashraf, M.A. Microalgae: A Potential Plant for Energy Production. Geol. Ecol. Landsc. 2017, 1, 104-120. [CrossRef]

5. Kucmanová, A.; Gerulová, K. Microalgae Harvesting: A Review. J. Environ. Manag. 2019, 27, 129-143. [CrossRef]

6. Chlorella Vulgaris-Microbewiki. Available online: https://microbewiki.kenyon.edu/index.php/Chlorella_vulgaris (accessed on 22 June 2021).

7. Moussa, D.T.; El-Naas, M.H.; Nasser, M.; Al-Marri, M.J. A Comprehensive Review of Electrocoagulation for Water Treatment: Potentials and Challenges. J. Environ. Manag. 2017, 186, 24-41. [CrossRef] [PubMed]

8. Vandamme, D.; Foubert, I.; Muylaert, K. Flocculation as a Low-Cost Method for Harvesting Microalgae for Bulk Biomass Production. Trends Biotechnol. 2013, 31, 233-239. [CrossRef]

9. Crittenden, J.C.; Trussell, R.R.; Hand, W.D.; Howe, K.J.; Tchobanoglous, G. MWH's Water Treatment Principles and Design, 3rd ed.; John Wiley \& Sons, Inc.: Hoboken, NJ, USA, 2012; p. 554.

10. Visigalli, S.; Barberis, M.G.; Turolla, A.; Canziani, R.; Berden Zrimec, M.; Reinhardt, R.; Ficara, E. Electrocoagulation-Flotation (ECF) for Microalgae Harvesting-A Review. Sep. Purif Technol. 2021, 271, 118684. [CrossRef]

11. Mollah, M.Y.A.; Schennach, R.; Parga, J.R.; Cocke, D.L. Electrocoagulation (EC)—Science and Applications. J. Hazard. Mater. 2001, 84, 29-41. [CrossRef] 
12. Bartley, M.L.; Boeing, W.J.; Dungan, B.N.; Holguin, F.O.; Schaub, T. PH Effects on Growth and Lipid Accumulation of the Biofuel Microalgae Nannochloropsis Salina and Invading Organisms. J. Appl. Phycol. 2013, 26, 1431-1437. [CrossRef]

13. Li, W.K.W. Temperature Adaptation in Phytoplankton: Cellular and Photosynthetic Characteristics. Prim. Product. Sea 1980, 259-279. [CrossRef]

14. Salvucci, M.E.; Crafts-Brandner, S.J. Inhibition of Photosynthesis by Heat Stress: The Activation State of Rubisco as a Limiting Factor in Photosynthesis. Physiol. Plant. 2004, 120, 179-186. [CrossRef] [PubMed]

15. Ras, M.; Steyer, J.P.; Bernard, O. Temperature Effect on Microalgae: A Crucial Factor for Outdoor Production. Rev. Environ. Sci. Bio/Technol. 2013, 12, 153-164. [CrossRef]

16. Jamshaid, M.; Khan, A.A.; Ahmed, K.; Saleem, M. Heavy Metal in Drinking Water Its Effect on Human Health and Its Treatment Techniques-A Review. Int. J. Biosci. 2018, 12, 223-240. [CrossRef]

17. Baierle, F.; John, D.K.; Souza, M.P.; Bjerk, T.R.; Moraes, M.S.A.; Hoeltz, M.; Rohlfes, A.L.B.; Camargo, M.E.; Corbellini, V.A.; Schneider, R.C.S. Biomass from Microalgae Separation by Electroflotation with Iron and Aluminum Spiral Electrodes. Chem. Eng. J. 2015, 267, 274-281. [CrossRef]

18. Fayad, N.; Yehya, T.; Audonnet, F.; Vial, C. Harvesting of Microalgae Chlorella Vulgaris Using Electro-Coagulation-Flocculation in the Batch Mode. Algal Res. 2017, 25, 1-11. [CrossRef]

19. Bleeke, F.; Quante, G.; Winckelmann, D.; Klöck, G. Effect of Voltage and Electrode Material on Electroflocculation of Scenedesmus Acuminatus. Bioresour. Bioprocess. 2015, 2, 36. [CrossRef]

20. Rahmani, A.; Zerrouki, D.; Djafer, L.; Ayral, A. Hydrogen Recovery from the Photovoltaic Electroflocculation-Flotation Process for Harvesting Chlorella Pyrenoidosa Microalgae. Int. J. Hydrog. Energy 2017, 42, 19591-19596. [CrossRef]

21. Sanchez-Galvis, E.M.; Cardenas-Gutierrez, I.Y.; Contreras-Ropero, J.E.; García-Martínez, J.B.; Barajas-Solano, A.F.; Zuorro, A. An Innovative Low-Cost Equipment for Electro-Concentration of Microalgal Biomass. Appl. Sci. 2020, 10, 4841. [CrossRef]

22. Can, O.T.; Bayramoglu, M.; Kobya, M. Decolorization of Reactive Dye Solutions by Electrocoagulation Using Aluminum Electrodes. Ind. Eng. Chem. Res. 2003, 42, 3391-3396. [CrossRef]

23. Water Quality Standards for Drinking Water: Busan Water Authority. Available online: https://www.busan.go.kr/water_en/ InstitutionalStandard (accessed on 10 September 2021).

24. Standard Reduction Potential Charts for Chemistry. Available online: https:/ /www.flinnsci.com/standard-reduction-potentialcharts / (accessed on 2 June 2021).

25. Rayleigh, L. On the Pressure Developed in a Liquid during the Collapse of a Spherical Cavity. Lond. Edinb. Dublin Philos. Mag. J. Sci. 1917, 34, 94-98. [CrossRef]

26. Naje, A.S.; Chelliapan, S.; Zakaria, Z.; Ajeel, M.A.; Alaba, P.A. A Review of Electrocoagulation Technology for the Treatment of Textile Wastewater. Rev. Chem. Eng. 2017, 33, 263-292. [CrossRef]

27. Sakuma, G.; Fukunaka, Y.; Matsushima, H. Nucleation and Growth of Electrolytic Gas Bubbles under Microgravity. International J. Hydrog. Energy 2014, 39, 7638-7645. [CrossRef]

28. Volanschi, A.; Nijman, J.G.H.; Olthuis, W.; Bergveld, P. Microcavity Electrodes Used as Single-Nucleation Site Electrodes for the Electrolysis of Water. Sens. Mater. 1997, 9, 223-240.

29. Fekete, É.; Lengyel, B.; Cserfalvi, T.; Pajkossy, T. Electrochemical Dissolution of Aluminium in Electrocoagulation Experiments. J. Solid State Electrochem. 2016, 20, 3107-3114. [CrossRef]

30. Vandamme, D.; Pontes, S.C.V.; Goiris, K.; Foubert, I.; Pinoy, L.J.J.; Muylaert, K. Evaluation of Electro-Coagulation-Flocculation for Harvesting Marine and Freshwater Microalgae. Biotechnol. Bioeng. 2011, 108, 2320-2329. [CrossRef]

31. Xiong, Q.; Pang, Q.; Pan, X.; Chika, A.O.; Wang, L.; Shi, J.; Jia, L.; Chen, C.; Gao, Y. Facile Sand Enhanced Electro-Flocculation for Cost-Efficient Harvesting of Dunaliella Salina. Bioresour. Technol. 2015, 187, 326-330. [CrossRef]

32. Zhou, W.; Gao, L.; Cheng, W.; Chen, L.; Wang, J.; Wang, H.; Zhang, W.; Liu, T. Electro-Flotation of Chlorella Sp. Assisted with Flocculation by Chitosan. Algal Res. 2016, 18, 7-14. [CrossRef]

33. Castellanos-Estupinan, M.; Sanchez-Galvis, M.; Garcia-Martinez, J.B.; Barajas-Ferreira, C.; Zuorro, A.; Barajas-Solano, A.F. Design of an Electroflotation System for the Concentration and Harvesting of Freshwater Microalgae. Chem Eng Trans 2018, 64, 1-6. [CrossRef]

34. Resistivity and Conductivity-Temperature Coefficients for Common Materials. Available online: https://www.engineeringtoolbox. com/resistivity-conductivity-d_418.html (accessed on 28 May 2021).

35. Gabrielli, C.; Huet, F.; Keddam, M.; Macias, A.; Sahar, A. Potential Drops Due to an Attached Bubble on a Gas-Evolving Electrode. J. Appl. Electrochem. 1989, 19, 617-629. [CrossRef]

36. Licona Buelvas, W.; Cecilia, K.; Ávila, P.; Realpe Jiménez, Á. Temperature as a Factor Determining on Water Electrolysis. Int. J. Eng. Trends Technol. 2014, 7, 1.

37. Cañizares, P.; Carmona, M.; Lobato, J.; Martínez, F.; Rodrigo, M.A. Electrodissolution of Aluminum Electrodes in Electrocoagulation Processes. Ind. Eng. Chem. Res. 2005, 44, 4178-4185. [CrossRef]

38. Picard, T.; Cathalifaud-Feuillade, G.; Mazet, M.; Vandensteendam, C. Cathodic Dissolution in the Electrocoagulation Process Using Aluminium Electrodes. J. Environ. Monit. 2000, 2, 77-80. [CrossRef] [PubMed] 